The Bioethics of Enhancement: Transhumanism, Disability, and Biopolitics

By Melinda C Hall

Lexington books; 194

Caio Weber Abramo*

\section{The Good}

Every once in a while, but still more often than it should, preposterous ideas appear and gain popularity. Very many were birthed or raised in the zoth century, falling within what Alan Sokal aptly coined 'fashionable nonsense,, ${ }^{1}$ and many still insist in surviving through the $21^{\text {st }}$ Century, trying to associate themselves with scientific and technological developments that few yet understand. Some of them are more or less harmless (such as 'quantum spirituality') while others carry an intrinsic danger to life and limb which, alas, has made an indelible presence in history itself.

Works such as The Bioethics of Enhancement serve the much needed purpose of exposing such doctrines for what they really are. Melinda Hall, of Stetson University, expertly uses philosophical discourse analysis to show how two such ideas, the human enhancement discourse and certain flavours of transhumanism, are inextricably linked not only to dubious philosophical positions, but also to social and political stances of the most abhorrent type. Furthermore, she convincingly describes how these discourses may reinforce the already dreary social and political environment of persons with disabilities.

Far from being interested in only abstract concerns, the book is rife with concrete examples of the dangers faced by those considered as disabled, ranging from psychological pressure to difficulties in access to healthcare to downright murder. Hall's presentation leaves little doubt of the relationship between these real events and society's conceptions on

DOI: 10.21552/delphi/2019/2/12

* Bachelor of Philosophy (Philosophy of Science, Epistemology and Logic), Universidade de Brasília and Master of Laws (Conflict and Security Law), Universiteit Utrecht. All views my own. For correspondence: <caiobfwa@gmail.com>.

1 Alan Sokal and Jean Bricmont, Intellectual Impostures (Profile Books 1999).

2 This view is called 'genetic determinism'. I will come back to this point in section II below.

3 These two points will be dealt with in Section III below. disabilities, conceptions which are repeated and reinforced by the discourses examined.

She is careful to point out that her object of study is not transhumanism as a whole nor the most philosophically sophisticated variants of it, but those which do have a developed theoretical literature and have found wide diffusion in society, be it in popular media or adoption by professional associations. Hall uses the frameworks of philosophy (particularly those developed by French political philosopher Michel Foucault, and the more recent fields of feminist theory and disability theory) to give (mostly) grounded, substantiated critiques to the mode of thinking and trans-philosophical implications of these branches of transhumanism and its unbridled advocacy for human enhancement and improvement' through eugenicist practices.

Of particular interest to her is how they relate to Foucault's bio-political question: Who will live? She shows that transhumanism focuses on control over the body, and carries value judgments on what is or isn't a worthy life; namely, the life of disabled, defective bodies is deemed less valuable than abled, 'normal' ones.

This is flawed from the start. A major pillar of the transhumanist conception of the world is that individuals are defined mostly by their genetic makeup: Our genes are the most important factor in establishing who we are and can even predict who we will be. ${ }^{2}$ Proponents of human enhancement suggest we correct our genes and physiology by whatever new-fangled technique is around in order to solve individual and social problems of all kinds. Some go as far as to advocate for the total abandonment of any body at all. Human bodies are bad, and 'defective' bodies are worse.

Some transhumanists are very careful to point out (and Hall does) they do not wish by this to attack people with disabilities, but merely advocate the 'prevention' of further defective births, and by individual choice alone, not by legal imposition. ${ }^{3}$ The individual is here considered as an entity in a vacuum, immune to social pressure, error or prejudice, an island of independent thought and pure intellectually-based action; another serious misgiving the book exposes. It shows how transhumanist and human enhancement discourse ignores or dismisses that some human problems aren't bodily problems at all, but social and political. It implies a simplistic (although popular) conception of humanity in which 
only the individual dimension exists. Yet humans are 'social' animals in the same sense we are made of atoms.

Hall addresses some examples of the misuse of scientific tools and concepts in transhumanist discourse, correctly criticising the philosophical positions associated with adopting them uncritically. Another that could be mentioned is the ample use of pseudo-scientific lingo in order to gain a veneer of respectability, a typical trait of fashionable nonsenses; besides the blatant technology name-dropping, see for instance how Nick Bostrom employs the language and symbols of mathematical systems theory to purely descriptive entities which are not (and perhaps can't be ever) measured or quantified. ${ }^{4}$ The use of this jargon is a mere rhetorical device, used to give readers the impression that these ideas have some basis in actual data and fact-based scientific research. No such data exists. This sits in opposition to the goal of scientific language, which is to provide clarity and precision.

\section{The Bad}

Hall's execution of this book is not without fault Some are rather minor (for instance, Chapter 4 is described as a Case Study, but the case chosen (negative genetic selection) doesn't receive a clear or systematic treatment), but two in particular stand out as more serious.

First, there is no clear explanation of what the author understands by 'social' and 'political construction', even though these concepts play central roles in the book's thesis. There is a general problem of only explaining concepts much after their initial use, but mostly other fundamental ideas are either clearly (albeit briefly) explained, or reference is given to the school of thought the author is adopting. But 'social' and 'political construction' were left out, and the text doesn't provide enough elements to construe them implicitly. Her approach is to 'provide examples of social construction of disability, ${ }^{5}$ but the examples fail to bring clarity. For instance, the assertion that illness can be 'politically constructed' by the decision to wage a war, in which soldiers are wounded. Here, 'illness' and 'disability' are used in a concrete sense, and social action is causally responsible for their real occurrence. But what is elsewhere discussed is how conditions are considered to be so, that is, how the concepts of 'illness' and 'disability' are socially constructed; the semantic or abstract sense. The relationship between these two, that is, the undeniable real occurrence and the way we socially understand it, is never addressed.

Not that an explanation would have saved the idea itself. Constructivism has been the target of serious bona fide philosophical criticism for decades, and it is quite difficult to construe it in consistent terms; some authors in fact say it is impossible. ${ }^{6}$ It isn't necessary to engage with the literature of an opposing field (though it would be salutary), but it is imperative to engage with some literature. The idea of 'social construction' is appealing and deserves study, but it can also be facile and abused, stretched beyond its philosophical ability to clarify to serve in defending inanities. ${ }^{7}$ In order for the central tenets of Hall's critique to survive, her definitions of social and political construction must be shown to be minimally coherent and not to fall into solipsism.

Second, some of the claims bearing on scientific issues are presented without evidence and can even be shown to be downright wrong. Hall's claim of a 'lack of evidence regarding the risk' of drinking alcohol during pregnancy is demonstrably false: Such evidence does exist. ${ }^{8}$ Whether they are valid or credible or not is certainly worth discussing (even by philosophers), but it must be discussed (especially by philosophers). This kind of unsubstantiated claim borders on the irresponsible. It also shows a lack of engagement with actual scientific methods and literature, not a small shortcoming in a work attempting to address topics such as genetics and medical research. This is the case even when the white-washing statements happen to be true; for instance, she is correct in pointing out that genetic determinism (mentioned above in section I) is not endorsed by the near totality of geneticists today, but doesn't make reference to any in particular, which wouldn't be dif-

4 Melinda C Hall, The Bioethics of Enhancement: Transhumanism Disability, and Biopolitics (Lexington books 2017) 25.

5 ibid 48.

6 See for instance Paul Boghossian, Fear of Knowledge: Against Relativism and Constructivism (Oxford University Press 2006).

7 Examples abound, but perhaps one of the most (in)famous is Bruno Latour's assertion that the bacillus that causes tuberculosis literally didn't in fact exist until it was observed under the microscope in 1882.

8 J Williams et al, 'Fetal Alcohol Spectrum Disorders' (2015) 136 Pediatrics. 
ficult. In fact, it is not hard either to scientifically demonstrate that strict genetic determinism is factually false, as evolutionary biologist Richard Lewontin does. ${ }^{9}$ In short, the otherwise well-constructed critique in this book becomes seriously threatened by the lack of attention to relevant literature and the (avoidable) introduction of flawed arguments and unjustified, unsupported statements and sweeping generalisations.

\section{The Ugly}

Popular proponents of transhumanism invariably present it in grandiose terms as a sort of panacea, selling promises not otherwise found outside works of science fiction or fantasy; Bostrom himself chose to depict the fight against death as a myth involving a dragon, and others of his non-transhumanist claims about reality have been likened to mere fiction. ${ }^{10}$ The very serious and worrying direct consequences of their ideas seem to be treated the same way, with easy and unrealistic solutions (or dismissals). Naturally they fail to adequately answer these legitimate concerns, going as far as attempting to unapologetically 'reclaim' eugenics itself as a putatively positive endeavour, refusing to address the fact that it and 'ideal body' ideologies are at the very heart of the greatest crimes in human history.

9 Richard Lewontin, The Triple Helix: Gene, Organism, and Environment (Harvard university press 2002).

10 See interview with physicist George Ellis in Sabine Hossenfelder Lost in Maths: How Beauty Leads Physics Astray (Basic Books 2018) 215 .

11 Law for the Prevention of Genetically Diseased Offspring (Gesetz zur Verhütung erbkranken Nachwuchses), enacted 14 July 1933; Law for the Protection of German Blood and German Honour (Gesetz zum Schutze des deutschen Blutes und der deutschen Ehre), enacted 15 September 1935.

12 Final Solution to the Jewish Question (Endlösung der Judenfrage), described in the Besprechungsprotokoll of the Wansee Conference held 20 January 1942, document available at: <https://www.ghwk.de/fileadmin/user_upload/pdf-wannsee/dokumente/protokoll-januar1942_barrierefrei.pdf> (accessed 31 January 2019).

13 See the caveat on Bostrom in ch 1. Yet, they insist that it would work this time.

14 ibid 19-20.
Perhaps the greatest flaw of The Bioethics of Enhancement is simply not going far enough in its criticism. Engaging with transhumanism as simply another perfectly acceptable intellectual exercise gives legitimacy to several of its core propositions which are anything but acceptable under any standards, particularly eugenics. Authors quoted by Hall unabashedly try to revive the terminology and ideology of eugenics, and this goes in itself unchallenged throughout the book. Not only eugenics has been utterly discredited as a scientific proposition, partially due to its reliance on genetic determinism, but the whole global legal order has been re-shaped since 1945 to repel its re-introduction in practice. The adoption of eugenicist policies, such as the so-called 'Nuremberg laws, ${ }^{11}$ have led to very concrete implications which need hardly be mentioned. ${ }^{12}$ Current proponents of re-branded eugenics are very aware of this danger, ${ }^{13}$ and claim that it should remain a personal choice of individuals, its adoption as official policy to be avoided. But no mechanism to prevent the transformation into law of the widespread social norms these authors advocate is given, and The Bioethics of Enhancement does not call them out on this glaring fault.

Granted, the focus of the book is not the overall deficiencies of transhumanism or human enhancement, but how aspects of these discourses affect people with disabilities. So perhaps one shouldn't ask of it what it didn't propose itself to do. But it does remain a work of Philosophy and we can hold it to the standards of that field, one of them being the search for the most fundamental questions, an exercise in exploring the limits and ultimate consequences or implications of ideas. Hall concludes that, despite the wish to improve quality of life by 'correcting' bodies using technological enhancement, transhumanism cannot be an ally of persons with disabilities. What seems clear enough is that transhumanist discourse is more concerned with constructing a post-human, which isn't recognisably human in any meaningful way (none the least for not having a physical body); in this kind of imposture, all human bodies are flawed..$^{14}$ It stands to reason it isn't an ally of persons with disabilities, since it doesn't seem to be an ally of any persons at all. 